\title{
PENGARUH CITRA PERUSAHAAN TERHADAP KEPERCAYAAN KONSUMEN DAN DAMPAKNYA PADA KEPUTUSAN PEMBELIAN ONLINE DI MARKETPLACE SHOPEE DI KABUPATEN BIREUEN Oleh : \\ Kamaruddin,
}

Fakultas Ekonomi Program Studi Manajemen Universitas Islam Kebangsaan Indonesia, Bireuen, Aceh

Email : barusanamal@gmail.com

Muhammad Ferdiananda Chadafi

Fakultas Ekonomi Program Studi Manajemen Universitas Islam Kebangsaan Indonesia, Bireuen, Aceh

Email : ferdianandach@gmail.com

\section{Article Info}

Article History :

Received 29 August - 2021

Accepted 06 Sept - 2021

Available Online 25 Sept 2021

Keyword :

\section{Abstract}

Along with the times, technological developments that continue to develop make the rapid dissemination of information entire of society through various media. One of the results is from the field of information technology that has developed through the use of internet technology. The application of internet technology has entered several aspects of life, such as information services, government, education, to trade or business. Before the invention of the internet, humans tended to do various traditional businesses, where buyers and sellers met each other to negotiate and make transactions. The purpose of this research is to see the determination of the company's image on consumer trust and its impact on online purchasing decisions on marketplace Shopee in Bireuen Regency. Population of this research is all people in Bireuen Regency who shop online on marketplace Shopee. Sample in this research amounted to 130 people. The sampling method using accidental sampling.Data analysis using SEM AMOS program.After regression using Structural Equation Model (SEM).The results showed that the company's image had a significant and positive effect on trust and online purchasing decisions at the marketplace Shopee in Bireuen Regency. Furthermore, trust partially mediates the relationship between company image and purchasing decisions.

Brand Image, Trust, Buying decision 


\section{PENDAHULUAN}

Seiring berkembangnya zaman, perkembangan teknologi yang terus berkembang membuat cepatnya penyebaran informasi di seluruh masyarakat melalui beragam media. Salah satu hasilnya yakni dari bidang teknologi informasi yang telah berkembang melalui pemanfaatan teknologi internet. Penerapan teknologi internet ini sudah memasuki beberapa segi kehidupan, seperti pelayanan informasi, pemerintahan, pendidikan sampai perdagangan atau bisnis. Sebelum ditemukannya internet manusia cenderung melakukan beragam bisnis secara tradisional, dimana pihak penjual dan pembeli saling bertemu, bernegosiasi dan melakukan transaksi.

Namun dengan adanya perkembangan globalisasi yaitu munculnya internet seketika merubah pandangan dan cara masyarakat dalam berbisnis dengan mengandalkan sistem berbasis online. $E$ Commerce juga memiliki perbedaan jika dibandingkan dengan bisnis tradisional (traditional commerce), dimana pada konsep tradisional commerce memungkinkan adanya pertemuan dan interaksi antara pembeli dan penjual secara langsung di pasar, toko atau tempat usaha lainnya. Sedangkan dalam konsep e-commerce, penjual dan pembeli tidak bertemu secara langsung melainkan pertemuan kedua belah pihak dijembatani oleh sebuah website yang menjadi tempat dalam melakukan transaksi dan apabila pembeli tertarik dan yakin, maka pembeli dapat membeli produk tersebut melalui website.

Salah satu marketplace terbesar yang ada di Indonesia adalah Shopee. Shopee menawarkan transaksi jual beli online yang menyenangkan, gratis, dan terpercaya via ponsel. Strategi market place berbasis mobile-app yang ditawarkan oleh shopee sukses memberikan pengalaman berbelanja online lebih efisien dan interaktif. Strategi nomor dua yakni promo gratis ongkir dan flash sale, menjadi daya tarik lebih banyak orang Indonesia untuk berbelanja di platform tersebut.
Salah satu cara agar seorang konsumen melakukan pembelian scara online adalah dengan adanya kepercayaan. Kepercayaan merupakan salah satu pondasi dari bisnis. Suatu transaksi bisnis antara dua pihak atau lebih akan terjadi apabila masing-masing saling mempercayai. Hasil penelitian yang dilakukan oleh Ilmiyah (2020) menyatakan bahwa kepercayan berpengaruh signifikan terhadap keputusan pembelian di marketplace Shopee di Mojokerto. Hal ini menyatakan bahwa Pengaruh keputusan pembelian semkain tinggi jika kepercayaan konsumen semakin.

Selain kepercayaan, citra perusahaan juga menjadi salah satu alasan mengapa seorang konsumen memutuskan untuk melakukan pembelian. Citra perusahaan merupakan persepsi yang ada didalam benak konsumen terhadap suatu perusahaan yang akan menjadi dasar perilaku selanjutnya. menurut Kotler \& Keller (2018) menyatakan citra perusahaan merupakan seperangkat dari keyakinan, ide, dan kesan yang dimiliki oleh seorang konsumen terhadap suatu perusahaan. Penelitian yang dilakukan oleh Putri (2019) menyatakan bahwa citra perusahaan memiliki pengaruh yang positif dan signifikan terhadap keputusan pembelian. Artinya, semakin tinggi kepercayaan maka semakin meningkat keputusan pembelian.

Pihak Shopee harus memikirkan strategi lain, agar keberlangsungan hidup perusahaan dapat terus berjalan, salah satunya membuat konsumen percaya terhadap Shopee, karena sebagian konsemen Shopee mengeluhkan mengenai kelemahan belanja online yaitu seperti, barang yang dikirim palsu, barang yang diterima konsumen tidak sesuai dengan display dan lain sebagainya.

Maksud dari penelitian ini adalah untuk memperoleh infomasi yang berkaitan dengan citra perusahaan dan kepercayaan konsumen dan dampaknya terhadap keputusan pembelian online pada marketplace Shopee di kabupaten Bireuen 


\section{KAJIAN PUSTAKA DAN PENGEMBANGAN HIPOTESIS \\ a. Keputusan Pembelian}

Keputusan pembelian adalah tahapantahapan yang dilewati konsumen untuk memutuskan melakukan pembelian atau tidak terhadap barang maupun jasa. Keputusan pembelian merupakan akumulasi dari beberapa tahapan yang dilakukan oleh konsumen sebelum membeli produk (Kotler \& Keller, 2018) Selanjutnya menurut Setiadi (2010) keputusan pembelian merupakan perilaku membelu yang dimaknakan sebagai kegiatan-kegiatan individu yang secara langsung terliba didalam pertukaran uang dengan barang maupun jasa. Sehingga keputusan yang diambil merupakan kumpulan dari sejumlah keputusan yang terstuktur. Dari pendapat ahli yang ada diatas, dapat diambil kesimpulan bahwa keputusan pembelian merupakan hasil akhir dari serangkaian proses yang dilakukan seseorang untuk sampai pada penentuan pilihan atas produk yang ingin dibeli.

\section{b. Kepercayaan}

Kepercayaan merupakan suatu hal yang sangat penting, terlebih lagi dalam proses jual beli. Karena ketika konsumen memiliki tingkat kepercayaan yang tinggi terhadap sesuatu, baik itu merek, produk dan sebagainya, mereka akan dengan senang hati untuk merelakan uang nya untuk membeli suatu produk. Menurut Nooteboom dalam Eka (2015) kepercayaan berkaitan dengan ketergantungan dan resiko, antara pemberi kepercayaan dan diberi kepercayaan. Menurut Kimery dan McCard dalam Andy (2014) menyatakan bahwa kepercayaan adalah kesediaan untuk menerima kelemahan dalam segala bentuk transaksi.

\section{c. Citra perusahaan}

Menurut Alma (2016) menyatakan bahwa citra merupakan kesan total dari apa yang seseorang persepsikan dan tahu tentang suatu objek. Karena citra yang baik merupakan perangkat yang kuat untuk konsumen dalam memilih produk. Lebih jauh menurut Kotler \& Keller (2018) menyatakan citra perusahaan merupakan seperangkat dari keyakinan, ide, dan kesan yang dimiliki oleh seorang konsumen terhadap suatu perusahaan.

\section{d. Hubungan Citra Perusahaan terhadap Kepercayaan}

Citra perusahaan merupakan persepsi yang ada didalam benak konsumen terhadap suatu perusahaan yang akan menjadi dasar perilaku selanjutnya. Citra perusahaan sangat penting dalam membangun kepercayaan kepada konsumen.

Penelitian yang dilakukan oleh Zamrudi (2016) dalam penelitiannya menyatakan bahwa citra perusahaan memiliki pengaruh positif terhadap kepercayaan. Karena citra perusahaan merupakan sesuatu yang pentingdalam menentukan kepercayaan, yang mencerminkan bahwa merek yang menarikdan berharga meningkatkan kepercayaan konsumen terhadap produk atau jasa yang terkait dengan merek. Penelitian selanjutnya dilakukan oleh Lien,et al (2015) menunjukkan bahwa citra perusahaan memiliki pengaruh positif terhadap kepercayaan.

Berdasarkan kajian empiris diatas, maka dapat diambil hipotesis sebagai berikut:

$\mathrm{H}_{1}$ : Citra perusahaan berpengaruh terhadap kepercayaan konsumen kepada marketplace Shopee di Kabupaten Bireuen.

\section{e. Hubungan Citra Perusahaan terhadap Keputusan Pembelian}

Citra perusahaan merupakan salah satu asset yang harus dimiliki oleh perusahaan. Karena citra perusahaan yang baik merupakan akan memberikan nilai yang positif di mata konsumen.

Studi empiris menunjukkan bahwa terdapat hubungan antara citra perusahaan terhadap keputusan pembelian. Hasil penelitian yang dilakukan Fure, et al (2015) menunjukkan bahwa citra perusahaan berpengaruh positift erhadap keputusan pembelian. Selanjutnya Hasil penelitian yang dilakukan oleh Putri (2019) menyatakan bahwa citra perusahaan 
memiliki pengaruh yang positif dan signifikan terhadap keputusan pembelian.

Berdasarkan kajian empiris diatas, maka dapat diambil hipotesis sebagai berikut:

$\mathrm{H}_{2}$ : Citra perusahaan berpengaruh terhadap keputusan pembelian online pada marketplace Shopee di Kabupaten Bireuen.

\section{f. Hubungan Kepercayaan terhadap Keputusan Pembelian}

Kepercayaan adalah harapan yang dimiliki oleh seseorang terhadap orang lain dalam melakukan transaksi berdasarkan ng dengan harapan yang tinggi. Kepercayaan menjadi faktor yang paling penting dalam membangun hubungan antara penjual dan pembeli. Studi empiris menunjukkan ada keterkaitan yang sangat erat antara kepercayaan terhadap keputusan pembelian.

Penelitian yang dilakukan oleh Roro (2018) menunjukkan bahwa bahwa kepercayaan memiliki pengaruh positif terhadap keputusan pembelian. Selanjutnya Rafidah (2017) dalam penelitian ini menunjukkan bahwa kepercayaan berpengaruh signifikan terhadap keputusan pembelian busana secara online.

Berdasarkan kajian empiris diatas, maka dapat diambil hipotesis sebagai berikut:

$\mathrm{H}_{3}$ : Kepercayaan berpengaruh terhadap keputusan pembelian online pada marketplace Shopee di Kabupaten Bireuen.

\section{g. Kepercayaan Memediasi Hubungan Citra Perusahaan terhadap Keputusan Pembelian}

Studi empiris menunjukkan bahwa terdapat hubungan kepercayaan yang memediasi secara positif antara citra perusahaan terhadap keputusan pembelian.

Seperti penelitian yang dilakukan oleh Virgo (2017) menunjukkan bahwa kepercayaan memediasi antara citra perusahaan terhadap keputusan pembelian.

Berdasarkan kajian empiris diatas, maka dapat diambil hipotesis sebagai berikut:

$\mathrm{H}_{4}$ : Kepercayaan memediasi hubungan antara citra perusahaan berpengaruh terhadap kepercayaan keputusan pembelian online pada marketplace Shopee di Kabupaten Bireuen.

\section{h. Kerangka Konseptual}

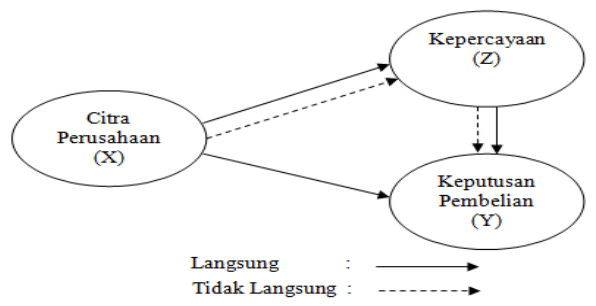

Gambar 1 : Kerangka Konseptual

\section{METODE PENELITIAN}

\section{a. Populasi dan Sampel}

Populasi dalam penelitian ini, adalah konsumen kota Bireuen yang pernah berbelanja melalui marketplace Shopee. Ukuran sampel yang sesuai dan ideal dalam analisis Structual Equation Model (SEM) dengan Software AMOS adalah 100 - 200, ukuran sampel adalah berkisar 5 - 10 kali jumlah parameter/indikator yang ada dalam satu model penelitian. Adapun jumlah indikator dalam model penelitian ini adalah sebanyak 13 indikator. Sehingga jumlah sampel dapat berjumlah 5 - 10 kali jumlah indikator dalam model, penelitian ini mengambil sampel sebanyak 10 kali dari jumlah indikator $(13 \times 10)=130$ sampel.

Dalam penelitian ini menggunakan teknik accidental sampling dalam mengambil sampel. Accidental sampling adalah teknik penentuan sampel yaitu siapa saja responden yang secara kebetulan bertemu dengan peneliti dapat digunakan sebagai sampel, bila dipandang orang yang kebetulan ditemui itu cocok sebagai sumber (Sugiyono, 2016).

\section{b. Teknik Pengumpulan Data}

Teknik pengumpulan data dalam penelitian ini menggunakan cara dengan penyebaran kuesioner kepada responden. Kuesioner merupakan teknik pengumpulan 
data yang dilakukan dengan cara memberi seperangkat pertanyaan atau pernyataan tertulis kepada responden untuk dijawabnya.

\section{c. Defenisi Operasional Variabel}

\section{Tabel 1}

Definisi Operasional Variabel

\begin{tabular}{|c|c|c|}
\hline Dimensi & $\begin{array}{c}\text { Definisi } \\
\text { Operasional }\end{array}$ & Indikator \\
\hline $\begin{array}{c}\text { Citra } \\
\text { Perusahaan } \\
(\mathrm{X})\end{array}$ & $\begin{array}{l}\text { Sebagai perangkat } \\
\text { keyakinan, ide, dan } \\
\text { kesan yang dimiliki } \\
\text { olehr seseorang } \\
\text { terhadapr suatu } \\
\text { merek, produk atau } \\
\text { perusahaan. }\end{array}$ & $\begin{array}{l}\text { 1.Kepribadian: } \\
\text { 2.Reputasi } \\
\text { 3.Nilai } \\
\text { 4.identitas } \\
\text { perusahaan } \\
\text { Harrison } \\
\text { dalam Sari } \\
\text { (2012) }\end{array}$ \\
\hline $\begin{array}{c}\text { Kepercayaan } \\
\text { (Z) }\end{array}$ & $\begin{array}{l}\text { Kepercayaan } \\
\text { adalah keinginan } \\
\text { bergantung pada } \\
\text { partner kerja sama } \\
\text { yang telah diyakini }\end{array}$ & $\begin{array}{l}\text { 1.Integritas } \\
\text { 2.Benovelence } \\
\text { 3.Competency } \\
\text { 4.Predictability } \\
\text { 5. Gefen dalam } \\
\quad \text { Yee dan } \\
\quad \text { Fazilarudean } \\
\quad(2010)\end{array}$ \\
\hline $\begin{array}{c}\text { Keputusan } \\
\text { Pembelian } \\
\text { (Y) }\end{array}$ & $\begin{array}{l}\text { Keputusan } \\
\text { pembelian } \\
\text { merupakan suatu } \\
\text { keputusan sebagai } \\
\text { pemilikan tindakan } \\
\text { dari dua atau lebih } \\
\text { pilihan alternatif } \\
\text { mengenai proses, } \\
\text { cara pembuatan } \\
\text { membeli dengan } \\
\text { mempertimbangka } \\
\text { n faktor lain tentang } \\
\text { apa yang dibeli, } \\
\text { dimana serta } \\
\text { membelinya } \\
\text { cara membayarnya. }\end{array}$ & $\begin{array}{l}\text { 1.Pengenalan } \\
\text { Kebutuhan } \\
\text { 2.Pencarian } \\
\text { Informasi } \\
\text { 3. Evaluasi } \\
\text { Alternatif } \\
\text { 4. Proses } \\
\text { Keputusan } \\
\text { Pembelian } \\
\text { 5.Perilaku Pasca } \\
\text { Pembelian } \\
\text { 6. (Kotler, 2013) }\end{array}$ \\
\hline
\end{tabular}

\section{d. Metodelogi Penelitian}

Setelah mengumpulkan data dan informasi dilapangan, maka untuk mengelola data dan informasi tersebut, penulis menggunakan metoda The Structural Equation Model (SEM) dalam model dan pengujian hipotesis, SEM atau model persamaan struktural adalah sekumpulan teknik-teknik statistik yang memungkinkan pengujian sebuah rangkaian hubungan yang relatif rumit, secara simultan (Ferdinand, 2011). Yang dimaksud dengan rumit adalah modelmodel simultan yang dibentuk melalui lebih dari satu variabel terikat pada saat yang sama berperan sebagai variabel bebas bagi hubungan berjenjang lainnya.

Dalam penelitian ini digunakan dua macam teknik analisis, yaitu :

- Analisis konfirmatori (confirmatory factor analysis) pada SEM yang digunakan untuk mengkorfirmatori faktor-faktor yang paling dominan dalam satu kelompok variabel.

- Regression Weight pada SEM yang digunakan untuk meneliti seberapa besar pengaruh antara variabel-variabel.

Menurut Ferdinand, (2011), terdapat tujuh langkah yang harus dilakukan apabila menggunakan permodelan Structural Equation Model (SEM). Sebuah permodelan SEM yang lengkap pada dasarnya terdiri dari dua bagian utama yaitu Measurement Model dan Structural model. Measurement Model merupakan model pengukuran untuk mengkonfirmasi indikator-indikator dari sebuah variabel laten, sedangkan model stuktural yang menggambarkan hubungan kausalitas antara dua atau lebih variable.

\section{PEMBAHASAN}

\section{a. Uji Validitas/Confirmatory Factory Analysis (CFA)}

- Menurut Ghozali (2014), indikator yang dikatakan valid apabila nilai loading factor nya $\geq 0,60$ dan nilai idealnya 0,70 . Pengujian validitas dalam penelitian ini, ditampilkan sebagai berikut:

Tabel 2

\section{Uji Validitas Sebelum Eliminasi}

\begin{tabular}{|c|c|c|c|}
\hline Indikator & Estimate & Cut Off & Kesimpulan \\
\hline CP1 &, 757 & $\geq 0,60$ & Valid \\
\hline CP2 &, 737 & $\geq 0,60$ & Valid \\
\hline CP3 &, 828 & $\geq 0,60$ & Valid \\
\hline CP4 &, 744 & $\geq 0,60$ & Valid \\
\hline K1 &, 778 & $\geq 0,60$ & Valid \\
\hline K2 &, 745 & $\geq 0,60$ & Valid \\
\hline K3 &, 589 & $\geq 0,60$ & Tidak Valid \\
\hline K4 &, 695 & $\geq 0,60$ & Valid \\
\hline KP1 &, 715 & $\geq 0,60$ & Valid \\
\hline KP2 &, 742 & $\geq 0,60$ & Valid \\
\hline KP3 &, 717 & $\geq 0,60$ & Valid \\
\hline
\end{tabular}




\begin{tabular}{|c|c|c|c|}
\hline Indikator & Estimate & Cut Off & Kesimpulan \\
\hline KP4 &, 468 & $\geq 0,60$ & Tidak Valid \\
\hline KP5 &, 764 & $\geq 0,60$ & Valid \\
\hline
\end{tabular}

Berdasarkan tabel diatas, indikator yang bernilai estimate di bawah 0,60 dinyatakan tidak valid, sehingga indikator yang bernilai di bawah 0,60, maka indikator tersebut harus di drop.

Tabel 3

Uji Validitas Sesudah Eliminasi

\begin{tabular}{|c|c|c|c|}
\hline Indikator & Estimate & $\begin{array}{c}\text { Cut } \\
\text { Off }\end{array}$ & Kesimpulan \\
\hline $\mathrm{CP} 1$ &, 757 & $\geq 0,60$ & Valid \\
\hline $\mathrm{CP} 2$ &, 737 & $\geq 0,60$ & Valid \\
\hline $\mathrm{CP} 3$ &, 828 & $\geq 0,60$ & Valid \\
\hline $\mathrm{CP} 4$ &, 744 & $\geq 0,60$ & Valid \\
\hline $\mathrm{K} 1$ &, 778 & $\geq 0,60$ & Valid \\
\hline $\mathrm{K} 2$ &, 745 & $\geq 0,60$ & Valid \\
\hline $\mathrm{K} 4$ &, 695 & $\geq 0,60$ & Valid \\
\hline $\mathrm{KP} 1$ &, 715 & $\geq 0,60$ & Valid \\
\hline $\mathrm{KP} 2$ &, 742 & $\geq 0,60$ & Valid \\
\hline $\mathrm{KP} 3$ &, 717 & $\geq 0,60$ & Valid \\
\hline $\mathrm{KP} 5$ &, 764 & $\geq 0,60$ & Valid \\
\hline
\end{tabular}

Berdasarkan tabel diatas, keseluruhan nilai estimate dari indikator penelitian memenuhi nilai cut off yaitu $\geq 0,60$.

\section{b. Uji Reliabilitas Konstruk}

Uji reliabilitas dilakukan dengan 3 cara yaitu Construct Reliability (CR), Average Variance Extracted (AVE/VE), dan Discriminant Validity (DV).

Tabel 4

Uji Reliabilitas Konstruk

\begin{tabular}{|c|c|c|c|c|}
\hline \multirow{2}{*}{ Variabel } & \multicolumn{2}{|c|}{$\begin{array}{c}\text { Construct } \\
\text { Reliability }\end{array}$} & \multicolumn{2}{c|}{$\begin{array}{c}\text { Variance } \\
\text { Extracted }\end{array}$} \\
\cline { 2 - 5 } & $\begin{array}{c}\text { Nilai } \\
\text { Perolehan }\end{array}$ & $\begin{array}{c}\text { Nilai } \\
\text { Cuff }\end{array}$ & $\begin{array}{c}\text { Nilai } \\
\text { Perolehan }\end{array}$ & $\begin{array}{c}\text { Nilai } \\
\text { Cut } \text { Off }\end{array}$ \\
\hline $\mathrm{CP}$ & 0,851 & $\begin{array}{c}\geq \\
0,7\end{array}$ & 0,588 & $\begin{array}{c}\geq \\
0,5\end{array}$ \\
\hline $\mathrm{K}$ & 0,783 & $\begin{array}{c}\geq \\
0,7\end{array}$ & 0,547 & $\begin{array}{c}\geq \\
0,5\end{array}$ \\
\hline $\mathrm{KP}$ & 0,824 & $\begin{array}{c}\geq \\
0,7\end{array}$ & 0,54 & $\mathbf{2}$ \\
\hline
\end{tabular}

Berdasarkan data dalam Tabel diatas dapat dijelaskan bahwa semua konstruk dalam model penelitian ini memiliki nilai reliabilitas dan convergent yang baik, sehingga model telah dapat diolah.

\section{c. Asumsi SEM}

- Uji Normalitas Data

Hasil penelitian menunjukkan bahwa tidak terdapat nilai C.R. (Critical Ratio) untuk skewness yang berada di atas nilai \pm 2,58 baik secara univariat maupun multivariat. Sehingga dapat dikatakan bahwa data penelitian yang digunakan telah memenuhi persyaratan normalitas data, atau dengan kata lain bahwa data dalam penelitian ini telah terdistribusi secara normal.

\section{- Uji Outlier Data}

Berdasarkan data observasi di atas menyebutkan tidak didapatkan nilai $\mathrm{p} 2<$ 0,05 . Sehingga data penelitian ini, tidak ada yang outlier.

\section{- Uji Multikolinearitas dan \\ Singularitas}

Berdasarkan hasil uji Multikolinieritas memperlihatkan nilai Determinant of sample covariance matrix sebesar 0,020 artinya nilai tersebut mencoba menjauh dari nol, sehingga dapat dikatakan bahwa tidak terdapat Multikolinieritas antar variabel.

\section{d. Uji Full Model}

Pengujian full model SEM bertujuan untuk melihat sejauh mana model dasar yang dibentuk dalam penelitian ini memenuhi kriteria goodness of fit sehingga model dapat menggambarkan fenomena penelitian. Adapun full model SEM dapat dilihat pada Gambar 2 dibawah ini:

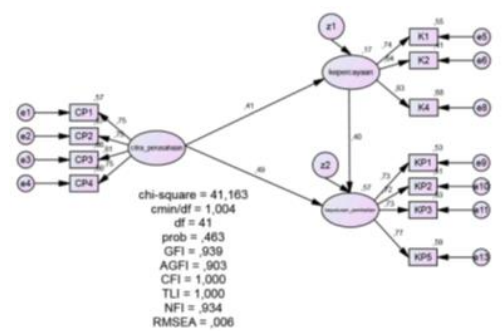

Gambar 2 Full Model

Untuk melihat hasil goodness of fit secara rinci dan evaluasi model dapat dijelaskan pada Tabel 5 sebagai berikut

Tabel 5 Goodness Of Fit

\begin{tabular}{lccc}
\hline $\begin{array}{c}\text { Goodness of } \\
\text { Fit Index }\end{array}$ & $\begin{array}{c}\text { Hasil } \\
\text { Analisis }\end{array}$ & $\begin{array}{c}\text { Cut-off } \\
\text { Value }\end{array}$ & $\begin{array}{c}\text { Evaluasi } \\
\text { Model }\end{array}$ \\
\hline $\mathrm{X}^{2}$ ChiSquare & 41,163 & $<\mathrm{Df}(56,6)$ & Baik \\
Probability & 0,463 & $\geq 0,05$ & Baik \\
\hline
\end{tabular}




\begin{tabular}{lccl}
\hline GFI & 0,939 & $\geq 0,90$ & Baik \\
AGFI & 0,903 & $\geq 0,90$ & Baik \\
CFI & 1,000 & $\geq 0,90$ & Baik \\
TLI & 1,000 & $\geq 0,95$ & Baik \\
CMIN/DF & 1,000 & $\leq 2$ & Baik \\
RMSEA & 0,006 & $\leq 0,08$ & Baik \\
\hline
\end{tabular}

Hasil analisis goodness of fit menunjukkan bahwa setelah dilakukan modifikasi ke semua kriteria nilai yang ditetapkan lebih baik dari sebelumnya, Dengan demikian secara keseluruhan model penelitian ini telah fit.

\section{e. Pengujian Pengaruh Langsung}

Untuk melihat seberapa besar pengaruh variabel eksogen (citra perusahaan) terhadap variabel intervening (kepercayaan) dan variabel endogen (keputusan pembelian) ditampilkan dalam Tabel 6:

Tabel 7 Pengaruh Langsung

\begin{tabular}{lllcccc}
\hline & & & Estimate & S.E. & C.R. & P \\
\hline $\mathrm{K}$ & $<-$ & $\mathrm{CP}$ &, 411 &, 115 & 3,700 & $* * *$ \\
$\mathrm{KP}$ & $<-$ & $\mathrm{CP}$ &, 493 &, 108 & 4,592 & $* * *$ \\
$\mathrm{KP}$ & $<-$ & $\mathrm{K}$ &, 402 &, 109 & 3,610 & $* * *$ \\
\hline
\end{tabular}

- Berdasarkan tabel diatas, didapatkan bahwa variabel citra perusahaan berpengaruh terhadap kepercayaan. Hal ditunjukkan pada nilai $p$ value $<0,05$ yaitu $(0,000<0,05)$ dengan nilai estimate sebesar 0,441 . Sehingga $\mathrm{H}_{1}$ yang menyatakan bahwa citra perusahaan berpengaruh terhadap kepercayaan konsumen kepada marketplace Shopee di Kabupaten Bireuen diterima.

- Berdasarkan tabel diatas, didapatkan bahwa variabel citra perusahaan berpengaruh terhadap keputusan pembelian. Hal ditunjukkan pada nilai $p$ value $<0,05$ yaitu $(0,000<0,05)$ dengan nilai estimate sebesar 0,493. Sehingga $\mathrm{H}_{2}$ yang menyatakan bahwa citra perusahaan berpengaruh terhadap berpengaruh terhadap keputusan pembelian online pada marketplace Shopee di Kabupaten Bireuen..

- Berdasarkan tabel diatas, didapatkan bahwa variabel kepercayaan berpengaruh terhadap keputusan pembelian. Hal ditunjukkan pada nilai $p$ value $<0,05$ yaitu $(0,000<0,05)$ dengan nilai estimate sebesar 0,402 . Sehingga $\mathrm{H}_{3}$ yang menyatakan bahwa Kepercayaan berpengaruh terhadap keputusan pembelian online pada marketplace Shopee di Kabupaten Bireuen diterima.

\section{f. Pengaruh Langsung, Tidak Langsung dan Pengaruh Total}

Untuk melihat pengaruh efek mediasi, terlebih dahulu harus melihat seberapa besar pengaruh langsung (direct effect) tidak langsung (indirect effect) dan pengaruh keseluruhan (total effect).

Tabel 8 Pengaruh Langsung, Tidak Langsung dan Pengaruh Total

\begin{tabular}{lccc}
\hline & CP & K & KP \\
\hline Direct Effects & & & \\
Kepercayaan & 0,411 & - & - \\
$\begin{array}{l}\text { Keputusan Pembelian } \\
\text { Indirect Effects }\end{array}$ & 0,493 & 0,402 & - \\
Kepercayaan & & & \\
Keputusan Pembelian & 0,167 & - & - \\
Total Effects & & & \\
Kepercayaan & 0,411 & - & - \\
Keputusan Pembelian & 0,663 & 0,402 & - \\
\hline
\end{tabular}

\section{g. Hasil Pengaruh Efek Mediasi}

Penjelasan mengenai hubungan variabel predikter (X), mediator (M) dan keluaran (Y), dijelaskan sebagai berikut:

Kepercayaan memediasi Hubungan citra perusahaan terhadap keputusan pembelian

\begin{tabular}{|c|c|c|c|c|}
\hline Input: & & Test statistic: & Std. Error: & p-value: \\
\hline a 0.411 & Sobel test: & 2.56654832 & 0.06437518 & 0.01027163 \\
\hline$b 0.402$ & Aroian test: & 2.51923416 & 0.06558422 & 0.01176104 \\
\hline$s_{a} 0.115$ & Goodman test: & 2.61663254 & 0.06314299 & 0.00888019 \\
\hline$s_{b} 0.109$ & Reset all & & Calculate & \\
\hline
\end{tabular}

Gambar 3 Hasil Sobel Tes

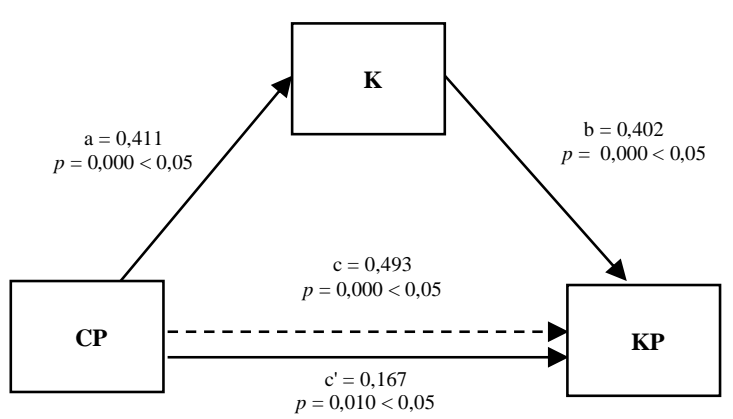




\section{Gambar 4 Hasil Uji Efek Mediasi}

Berdasarkan Gambar 4 dan Kriteria Mediasi (Baron \& Kenny, 1986) dapat disimpulkan bahwa koefesien a, b, c dan c' jalur langsung adalah signifikan. Sehingga dapat disimpulkan terjadi partial mediation atau dengan kata lain variabel Kepercayaan memediasi hubungan antara citra perusahaan berpengaruh terhadap kepercayaan keputusan pembelian online pada marketplace Shopee di Kabupaten Bireuen, sehingga $\mathrm{H}_{4}$ diterima.

\section{i. Hubungan Citra Perusahaan terhadap Kepercayaan}

Hasil penelitian menunjukkan bahwa citra perusahaan berpengaruh terhadap kepercayaan. Nilai estimate yang bernilai positif menunjukkan bahwa citra perusahaan memberikan pengaruh positif terhadap kepercayaan konsumen kepada marketplace Shopee di Kabupaten Bireuen. Hal ini menjelaskan semakin baik citra perusahaan maka semakin meningkat pula kepercayaan konsumen,

Hasil penilitian ini sejalan dengan penelitian yang dilakukan oleh Zamrudi (2016) dalam penelitiannya menyatakan bahwa citra perusahaan memiliki pengaruh positif terhadap kepercayaan. Selanjutnya penelitian yang dilakukan oleh Lien, et al (2015) menunjukkan bahwa citra perusahaan memiliki pengaruh positif terhadap kepercayaan.

\section{j. Hubungan Citra Perusahaan terhadap Keputusan Pembelian}

Hasil penelitian menunjukkan bahwa citra perusahaan berpengaruh terhadap keputusan pembelian. Nilai estimate yang bernilai positif menunjukkan bahwa citra perusahaan memberikan pengaruh positif terhadap keputusan pembelian online pada marketplace Shopee di Kabupaten Bireuen.

Hasil penelitian ini sejalan dengan penelitian yang dilakukan Fure, et al (2015) menunjukkan bahwa citra perusahaan berpengaruh positift erhadap keputusan pembelian. Selanjutnya Hasil penelitian yang dilakukan oleh Putri (2019) menyatakan bahwa citra perusahaan memiliki pengaruh yang positif dan signifikan terhadap keputusan pembelian.

\section{k. Hubungan Kepercayaan terhadap Keputusan Pembelian}

Hasil penelitian menunjukkan bahwa kepercayaan berpengaruh terhadap keputusan pembelian. Nilai estimate yang bernilai positif menunjukkan bahwa kepercayaan memberikan pengaruh positif terhadap keputusan pembelian online pada marketplace Shopee di Kabupaten Bireuen.

Kepercayaan menjadi faktor yang paling penting dalam membangun hubungan antara penjual dan pembeli. Studi empiris menunjukkan ada keterkaitan yang sangat erat antara kepercayaan terhadap keputusan pembelian.

Hasil penilitian ini sejalan dengan penelitian yang dilakukan oleh Roro (2018) menunjukkan bahwa bahwa kepercayaan memiliki pengaruh positif terhadap keputusan pembelian. Selanjutnya Kurnia (2016) hasil penelitian juga menunjukkan bahwa kepercayaan berpengaruh signifikan terhadap keputusan pembelian busana secara online.

\section{Kepercayaan Memediasi Hubungan Citra Perusahaan terhadap Keputusan Pembelian \\ Hasil penelitian menujukkan bahwa} kepercayaan memediasi hubungan antara citra perusahaan terhadap keputusan pembelian. Jalur a, b, c dan c' menujukkan signifikan, artinya kepercayaan memediasi secara partial hubungan antara citra perusahaan berpengaruh terhadap kepercayaan keputusan pembelian online pada marketplace Shopee di Kabupaten Bireuen.

Hasil penelitian ini sejalan dengan Seperti penelitian yang dilakukan oleh (2017) menunjukkan bahwa kepercayaan memediasi antara citra perusahaan terhadap keputusan pembelian. 


\section{KESIMPULAN}

Dari penelitian ini dapat disimpulkan bahwa citra perusahaan berpengaruh signifikan dan positif terhadap kepercayaan dan keputusan pembelian online pada marketplace Shopee di Kabupaten Bireuen. Selanjutnya kepercayaan berpengaruh positif dan signifikan terhadap keputusan pembelian online pada marketplace Shopee di Kabupaten Bireuen. Dapat dijelaskna bahwa untuk meningkatkan daya beli masyarakat Bireuen dapat dimulai dengan membangun citra perusahaan yang kemudian akan meningkatkan kepercayaan konsumen.

\section{DAFTAR REFERENSI}

Alma, Buchari. (2016). Manajemen Pemasaran dan Pemasaran Jasa. Alfabeta : Bandung

Andy P, Mahkota. Imam Suyadi. Riyadi. (2014). Pengaruh Kepercayaan Dan Kenyamanan Terhadap Keputusan Pembelian Online (Studi Pada Pelanggan Website Ride Inc). Jurnal Administrasi Bisnis (JAB)| Vol. 8 No. 2 Maret 2014. Fakultas Ilmu Administrasi, Universitas Brawijaya. Malang. Indonesia.

Eka, Kesuma. Amr. Shabri (2015).

Pengaruh Kualitas Pelayanan Dan Kepercayaan Terhadap Kepuasan Pelanggan Pada Sulthan Hotel Banda Aceh. Jurnal Manajemen ISSN2302-0199. Magister Manajemen Program Pasca Sarjana Fakultas Ekonomi Universitas Syiah Kuala Banda Aceh. Indonesia.

Fure ,Ferdyanto., Laplan, Joyce., Taroreh., Rita. (2015). Pengaruh Brand Image, Kualitas Produk dan Harga Terhadap Keputusan Pembelian Konsumen di J.CO Manado.Jurnal EMBA ISSN 2303-1174, Vol.3 No.1, hal. 367-377.

Hair, J. F., Black, W. C., Babin, B. J., \& Anderson, R. E. (1998). Muttivatiate Data analysis (Seventh Ed). Pearson Prentice Hall
Khafidatul, Ilmiyah \& Indra, K. (2020). Pengaruh Ulasan Produk, Kemudahan, Kepercayaan, Dan Harga Terhadap Keputusan Pembelian Pada Marketplace Shopee Di Mojokerto. Jurnal Manajemen, Volume 6- Nomor 1, Juni 2020 31-42.

Kotler, Philip. \&Kevin Lane Keller, (2018), Manajemen Pemasaran, Jilid 2, Edisi 13, Jakarta : Erlangga

Lien, Che-Hui., Wen, Min-Jye., Huang., LiChing., Wu, Kuo-Lung. (2015). Online Hotel Booking : The Effects of Brand Image, Price,Trust and Value on Purchase Intentions. Asia Pacific Management Review

Putri, N, A, \& Sri S, I. (2019). Factors Driving Purchasing Decisions on Shopee. Jurnal Komunikasi, Media dan Informatika Vol. 8 No. 2 /November 2019 hal 69-77

Rafidah, Inas \& Djawoto. (2017). Analisis Keamanan, Kemudahan Dan Kepercayaan Terhadap Keputusan Pembelian Secara Online Di Lazada, ISSN 24610593, Vol. 6, No. 2, Februari 2017.

Roro, F, Febriani. Budi Sudaryanto. 2018. Pengaruh brand image dan Kualitas Layanan terhadap kepercayaan dan Keputusan Pembelian Pada took online (Studi pada konsumen Olx.co.id dikota Semarang). Journal of management Volume7, Nomor 2 ,Tahun2018, ISSN(Online):2337-3792. Departemen Manajemen Fakultas Ekonomika dan Bisnis,Universitas Diponegoro.

Setiadi, Nugroho J. 2010. Perilaku Konsumen. Cetakan 4. Edisi Revisi. Jakarta : Kencana

Sugiyono. (2016). Metode Penelitian Kuantitatif, Kualitatif, dan $R \& D$ (p. 407).

Virgo, S \& Celeste. (2017). Pengaruh Reputasi Perusahaan Terhadap Keputusan Pembelian Dengan Kepercayaan Konsumen Sebagai Variabel Intervening (Studi Kasus 
Pada Konsumen Air Minum Dalam Kemasan Galon Merek Aqua Di Kecamatan Tanjung Priok Jakarta Utara.) Jurnal Akuntansi Manajerial ISSN (E): 2502-6704 Vol. 2, No. 2, Juli-Desember 2017: 24-36 .

Zamrudi, $\quad$ Z., $\quad$ Suyadi, $\quad$ I.,\& Abdillah,Y.(2016).The Effect ofSocial Commerce Construct and Brand Image on Consumer Trust and Purchase Intention. Jurnal Universitas Brawijaya,1-13. 